www.jmscr.igmpublication.org

Index Copernicus Value: 79.54

ISSN (e)-2347-176x ISSN (p) 2455-0450

crossrefDOI: https://dx.doi.org/10.18535/jmscr/v7i3.109

\title{
Necrotizing Fasciitis of the breast in a non diabetic postmenopausal woman a Case report with review of Literature
}

\section{Authors \\ Dr Rizwan Ahmad, Dr Mohammad Eqbal Ahmad}

\section{Introduction}

Necrotizing fasciitis of the breast is a rare condition that has a high morbidity if treatment is delayed.

There are only a few cases reported in literature and is stil an often missed condition Mistake for cellulitis or abscess of the breast.

Necrotizing fasciitis is an aggressive infection of the skin subcutaneous tissue and fascia Mainly affecting the extremities, abdominal wall or perineum, it rarely involves the breast.

\section{Case Report}

68 year old woman, presented to the emergency department with Complaints of pain and foul smelling discharge from her left breast For the past 4 days prior to admission.

She is a known case of hypertension for 2 years and ACS (Details not known) there was no history of trauma, fever, chills, and previous breast surgeries.

On examination, GC fair, HR:-104lmin:$100 \mathrm{lmmHg}$,a $15 \mathrm{~cm} x 12 \mathrm{~cm}$ necrotic

Patch was seen involving all four quadrants and the nipple areola complex.

The lesion was the tense and tender. The surrounding skin was erythematous Tense and tender with local warmth Investigations showed
Elevated Total counts (16100cells/mm3)

Decreased hemoglobin $(10.2 \mathrm{gm} / \mathrm{dl})$

Ultrasound showed diffuse subcutaneous and Glandular inflammation with edema of left breast With axillary lymphadenopathy.

\section{Treatment}

Patient was taken up for emergency wound debridement under General Anaesthesia the same day and started on inj. Pipracillin, tazobactum And inj. Metronidazole. devascularized tissue was removed along with Extensive debridment. Postoperatively daily wound dressing was done.

Tissue culture and sensivity showed growth of pseudomonas Aeruginosa Sensitive to ciprofloxacin and the same was started.

Tissue biopsy of the breast parenchyma showed features of suppurative Necrosis. thrombosed blood vessels. areas of periductal inflammation and Extensive areas of gangrenous necrosis in the subcutaneous plane extending To subcutaneous fat.

Patient was taken up for secondary suturing on POD\#14, and is now Completely disease free with healthy wound.

\section{Conclusion}

Necrotizing Fasciitis of the breast in aggressive soft tissue infection Which can be life threatening. 
Early surgical intervention and IV antibiotic cover can greatly reduce

The high morbidity and mortality associated with necrotizing fasciitis of the breast.

Due to the rare nature of the condition it can easily be misdiagnosed, Hence if patient presents with feature consistent with abscess ot Cellulitis Of the breast it is always good to have necrotizing fasciitis as a differential.

Histopathological examnination to confirm the absence of malignancy is Mandatory.

\section{References}

1. Fayman K, Wang K, Curran R.A case report of primary necrotizing Fasciitis of the breast. A rare but deadly entity requiring rapid surgical Management. Inj.J surg case Rep.2017 jan 23:31:221-4.

2. Mufty H.Seets A,Christiaens MR. An atypical case of necrotizing Fasciitis of the breast. Acta Chir Belg.2014 Jun:114 (3):215-8.

3. Ward ND, Harris JW, Sloan DA. Necrotizing Fascitis of the breast requiring Emergent Radical Mastectomy ,Breast J.2017 Jan;23( 1):95-9.

4. ALSareef B, ALSaleh N.Necrotizing fasciitis of the breast: Case Report With Literature Review.Case Rep Surg.2018;2018:1370680.

5. Rajakannu M, Kate V, Ananthakrishnan N. Necrotizing infection of the Breast mimicking carcinoma. Breast J.2006Jun;12( 3):266-7.

6. Yaji P,Bhat B.EH. Primary Necrotizing Fasciitis of the breast:case Report and Brief Review of Literature .J Clin Diagn Res JCDR.2014 Jul;8 (7) : ND01-2.. 